\title{
ALIRAN PEMIKIRAN EKONOMI ISLAM KONTEMPORER
}

DEWI/90100118101

EKONOMI ISLAM C

dewiambangi@gmail.com

Ekonomi Islam merupakan hasil pemikiran para muslim yang sumber kepada nilai-nilai Islam yaitu al-Qur'an dan al-Hadits (Maulidizen Ahmad, 2017). Pada awal dekade 1980-an, terjadi beberapa perbedaan pendapat diantara para pakar ekonomi Islam mengenai interpretasi atas istilah-istilah dan konsep-konsep tertentu dalam al-Qur'an dan as-Sunnah. Dan berbagai perbedaan lainnya. Namun demikian, hakekat pada permasalahan perbedaan di atas, sesungguhnya para pemikir ekonomi Islam pada masa kontemporer sepakat akan hal filosofi-filosofi dasar syari'ah Islam yaitu dengan berbasis pada al-Qur'an dan as-Sunnah (Santoso, 2016).

Para cendekiawan muslim dan para ekonom muslim merujuk dan menyandarkan semua kegiataan ekonominya pada sumber hukum utama Islam yakni Al-Qur'an dan Sunnah. Dengan hal tersebut dapat diketahui bahwa pemikiran ekonomi mikro islam telah menempuh perjalanan sejarah yang sangat panjang. Pemikiran-pemikiran ekonomi ini dimulai sejak masa Rasulullah SAW., Khulafaur al-Rasyidin, dan mulai dibukukan pada abad ke-2 sampai dengan ke-5 H oleh Abu Yusuf dan al-Syatibi, Abu Ubaid, Yahya bi Umar, al-Mawardi dan al-Ghazali. Sempat mengalami kekosongan sekitar satu abad lamanya. Namun, pada abad ketujuh hijriah sampai dengan kesembilan hijriah muncul tiga pemikir ekonomi islam, yakni ibnu Taimiyah, ibnu Khaldun dan al-Maqrizi. Pemikiran ekonomi yang monumental itu sempat berhenti beberapa abad lamanya hingga berkembang kembali pada pertengahan abad ke-20 dengan munculnya beberapa pemikir ekonomi Islam kontemporer (Nurhaeti \& Departement, 2019). Pemikiran ekonomi Islam kontemporer dapat dikategorikan dalam tiga kelompok aliran pemikiran yaitu: Aliran Iqtisaduna, Aliran Mainstream, dan Aliran Alternative. 
Aliran Iqtisaduna yang dipelopori oleh Baqir As-Sadr sehingga aliran ini juga dikenal dengan Mazhab Baqir As-Sadr. Baqir As-Sadr mempunyai nama lengkap Muhammad Bagir Al Sadr Ash-Shahid dilahirkan di Kadhimiyeh pada 25 Dzulqaidah 1353 H/ 1 Maret 1935 M (Choiriyah, 2016). Ia merupakan penyumbang pemikiran pada aliran ini. Pola utama aliran ini adalah pemikiran tentang pemecahan masalah ekonomi yang muncul karena adanya distribusi yang tidak merata dan adil sebagai pengaruh dari ekonomi kapitalis yang menguntungkan pihak yang kuat dan kaya. Pemahaman ekonomi iqtisaduna beranggapan bahwa puncak permasalahan ekonomi adalah bukan karena sumber daya yang tidak terbatas, tetapi karena ketamakan manusia yang tidak terbatas. Faham mazhab ekonomi ini menganggap bahwa segala sumber daya alam adalah tidak terbatas. Oleh karenanya beberapa pakar ekonomi Islam bependapat bahwa pemilik absolut harta kekayaan alam adalah Allah subuhanu wa ta'ala (Tamsir, 2019). Sehingga merupakan hal yang tidak mungkin jika sumber daya alam ini terbatas, sedangkan yang menciptakan, memiliki dan mengaturnya adalah Allah Subuhanahu wa ta 'ala.

Sejalan dengan itu, terdapat pandangan Ilmu ekonomi yang menyatakan bahwa masalah ekonomi timbul karena adanya masalah kelangkaan sumber daya ekonomi (scarcity) dibandingkan dengan kebutuhan manusia yang sifatnya tidak terbatas. Dalam hal ini, mazhab Baqir As-Sadr menolak pengertian ilmu ekonomi tersebut sebab dalam Islam telah ditegaskan bahwa Allah Swt. telah menciptakan makhluk di dunia ini termasuk manusia dalam kecukupan sumber daya ekonomi sebagaimana ditegaskan dalam firman-Nya. Disisi lain, mazhab Baqir As-Sadr juga menolak anggapan bahwa kebutuhan manusia sifatnya tidak terbatas. Sebab, dalam kebutuhan tertentu misalnya makan dan minum manakala perut sudah merasa kenyang maka dia sudah merasa puas karena kebutuhannya telah terpenuhi. Ini sesuai dengan penjelasan dalam konsep law of diminishing marginal utility bahwa semakin banyak barang dikonsumsi maka pada titik tertentu justru akan menyebabkan tambahan kepuasan dari setiap tambahan jumlah barang yang dikonsumsi akan semakin berkurang. Selanjutnya, menurut mazhab Baqir As-Sadr persoalan pokok yang dihadapi oleh seluruh umat manusia di dunia ini adalah masalah distribusi kekayaan yang tidak merata. Bagaimana anugerah yang 
diberikan Allah SWT kepada seluruh makhluk termasuk manusia ini bisa di distribusikan secara merata dan proporsional. Menurut mazhab Baqir As-Sadr untuk mewujudkan hal tersebut maka ada beberapa langkah yang dilakukan yaitu: pertama, mengganti istilah ilmu ekonomi dengan istilah iqtishad yang mengandung arti bahwa selaras, setara, dan seimbang (in between). Kedua, menyusun dan merekonstruksi ilmu ekonomi tersendiri yang bersumber dari Al-Qur'an dan Assunnah (Khoir, 2010).

Berbeda dengan aliran Iqtisaduna, pada aliran mainstream sendiri yaitu pola utama pemikirannya merupakan kebalikan dari Iqtisaduna. Perbedaannya adalah puncak permasalahan ekonomi, menurut mereka masalah ekonomi dikarenakan kekurangan (scarcity). Maksudnya adalah segala sumber daya alam adalah terbatas tetapi keperluan manusia yang tidak terbatas. Untuk itu manusia diarahkan untuk melalukan aktivitas ekonomi berdasarkan kepada skala prioritas dalam memenuhi kebutuhan manusia dengan tetap berpegang teguh kepada al-Qur'an dan al-Hadits. Lebih jelas mazhab mainstream menjelaskan bahwa memang secara keseluruhan tidak terjadi kesenjangan antara jumlah sumber daya ekonomi dengan kebutuhan manusia artinya ada keseimbangan (equilibrium). Namun secara relatif pada satu waktu tertentu dan pada tempat tertentu tetap akan dijumpai persoalan kelangkaan tersebut. Jadi sampai disini tidak ada perbedaan antara ekonomi konvensional dengan ekonomi Islam. Perbedaannya hanya pada mekanisme menyelesaikan masalah ekonomi yang menurut mazhab mainstream harus merujuk pada al-Qur'an dan Assunnah (Khoir, 2010). Adapaun Tokoh-tokoh utama pada aliran ini yaitu Muhammad abdul Mannan, Muhammad Nejatullah Siddiqi, Syed Nawab Haidar Naqvi, dan Monzer Kahf.

Terakhir aliran alternatif yang merupakan aliran kritis secara ilmiah terhadap ekonomi Islam, baik sebagai ilmu maupun sebagai peradaban. Aliran ini mengkritik kedua aliran kontemporer sebelumnya. Aliran Iqtiṣādunā dikritik karena dianggap berusaha mengemukakan sesuatu yang baru yang sebenarnya sudah ditemukan oleh tokoh-tokoh klasik sebelumnya, sedangkan aliran mainstream 
dikritik sebagai aliran serapan dari neo-klasik tetapi mengahapuskan elemen ribā serta menambah zakat dan akad, sehingga tidak ada keaslian pada aliran ini.

Tokoh aliran ini adalah Timur Kuran Timur Kuran, Jomo dan Muhammad Arif. Sesuai namanya aliran kritis maka nada kritis merupakan ciri khas aliran ini. Menurutnya analisis kritis bukan saja terhadap sosialisme dan kapitaisme tetapi juga pada konsep ekonomi Islam. Sehingga ekonomi Islam adalah suatu wacana yang masih bisa diperdebatkan kebenarannya karena merupakan suatu tafsiran manusia terhadap Al-Qur'an dan Assunnah yang perlu diuji dan dikaji terusmenerus (Khoir, 2010). Diyakini bahwa Islam pasti benar, tetapi ekonomi Islam sebagai sebuah tafsir terhadap ajaran Islam belum tentu benar, dan seandainya benar maka kebenaran itu tidak bersifat mutlak. Semua proposisi kebenaran yang diajukan oleh ekonomi Islam juga harus diuji kebenarannya sebagaimana proposisi konvensional. Maka semua hasil dari uji kebenaran ini merupakan sebuah tradisi ilmiah yang akan menguji sejauh mana tingkat validitas dari sebuah konsep ekonomi Islam. tentunya sebagi sebuah kritis maka nada kritis harus ditakar dengan seksama dan proporsional (Abidin, 2015). 


\section{DAFTAR PUSTAKA}

Abidin, Z. (2015). Mapping Pemikiran Akademisi Dalam Madzhab Ekonomi Islam Kontemporer. Iqtishadia: Jurnal Ekonomi \& Perbankan Syariah, 1(2), 263.

Choiriyah. (2016). Pemikiran Ekonomi Muhammad Baqir Ash-Sadr. Islamic Banking, 2(1), 49-58.

Khoir, M. (2010). Pemikiran Dan Mazhab Ekonomi Islam Kontemporer. Balance Economics, Bussiness, Management And Accounting Journal, Vii(12), 15-26.

Maulidizen Ahmad. (2017). Pemikiran Dan Kontribusi Tokoh Ekonomi Islam Klasik Dan Kontemporer. Jurnal Deliberatif; Jurnal Ilmiah Hukum, 1(1), 4262.

Nurhaeti, N. \&, \& Departement. (2019). Pemikiran Ekonomi Mikro Islam Dalam Lintasan Sejarah Nurrohman. Jurnal Ilmu Akuntansi Dan Bisnis Syariah, 1(2), $226-232$.

Santoso, S. (2016). Sejarah Ekonomi Islam Masa Kontemporer. An-Nisbah: Jurnal Ekonomi Syariah, 3(1), 60-86.

Tamsir, S. Dan. (2019). Rekonstruksi Konseptual Kepemilikan Harta Perspektif Ekonomi Islam (Studi Kritis Kepemilikan Harta Sistem Ekonomi Kapitalisme) Sirajuddin1,. Laa Maisyir, 6(2), 211-225. 